\title{
46. LEG 27 CEPHALOPODA
}

\author{
Graeme R. Stevens, New Zealand Geological Survey, Department of Scientific and
}

Industrial Research, Lower Hutt, New Zealand

\section{COLEOIDEA \\ BELEMNITIDA \\ Family Belemnopsidae \\ cf. Parahibolites, sp. indet. \\ (Plate 1, Figures 1-3)}

Material: One guard (Plate 1, Figure 1). Sample 263$26-2,108-110 \mathrm{~cm}$. Cuvier Abyssal Plain, $23^{\circ} 20^{\prime} \mathrm{S}$, $110^{\circ} 58^{\prime} \mathrm{E}$. Water depth 5065 meters. Sample from 698.5 to 708 meters below the sea floor. Specimen deposited in the World Mollusca Collection, New Zealand Geological Survey, Lower Hutt, New Zealand. Specimen WM 11629.

Dimensions: Length of guard: $36 \mathrm{~mm}$; diameter of guard at anterior end: $7 \mathrm{~mm}$.

Description: Guard moderately elongate. Length about six times maximum diameter. Outline symmetrical and nonhastate. Some $10 \mathrm{~mm}$ from the apex, the sides of the guard curve strongly, producing a short, sharp-pointed apical region. Apical angle $36^{\circ}$. Apex central. Profile nonhastate and probably symmetrical. Stem and apical cross-sections circular. Alveolar cross-sections not known. Apical line central. Neither grooves nor lateral lines appear to be present.

Discussion: The surface of the guard is coated with a closely adherent layer of clay, apparently impregnated with manganese oxides. An unsuccessful attempt was made with an airbrasive machine to remove this adherent layer. The characters of the guard have therefore been studied using a series of polished crosssections, cut after the guard was placed in a plastic embedding compound (Plate 1, Figures 2, 3).

Study of the cross-sections showed that the alveolar region is absent, and this has prevented more precise identification of the guard.

Initial examination of the cross-sections showed that the guard could be assigned to either the Dimitobelidae (e.g., Peratobelus, Dimitobelus) or Belemnopsidae (e.g., Neohibolites, Parahibolites). These two possibilities may be briefly discussed:

The guard of Peratobelus is characterized by long ventrolateral grooves, extending for the length of the alveolar and stem regions. The guard of Dimitobelus, on the other hand, has the ventrolateral grooves confined to the alveolar region and anterior part of the stem region. Therefore, if specimen WM 11629 was a Peratobelus the grooves would almost certainly appear in at least the most anterior cross-section (Plate 1, Figure 2).

It is difficult to evaluate exactly how much is missing of the anterior portion of the guard of WM 11629, but judging from the proportions of the remaining guard and from the observation that many belemnite guards frequently develop lines of weakness and hence often break at about the position of the protoconch (Stevens, $1965 \mathrm{~b}$ ), it is possible that very little of the anterior part of the stem region has been lost. There is a strong possibility, therefore, that if specimen WM 11629 was a Dimitobelus, the cross-sections would show some sign of the presence of ventrolateral grooves, or at least the strongly developed lateral lines that are their continuations posteriorly (Stevens, 1965b, figs. 26 and 29).

The cross-sections of specimen WM 11629-circular in both apical and stem regions-and centrally placed apical line, together tend to deny identification with Dimitobelidae, as both Peratobelus and Dimitobelus usually show depressed stem and apical cross-sections and eccentric apical line (although the Maestrichtian $D$. hectori Stevens has circular stem cross-sections and central apical line). It is concluded, therefore, that the balance of evidence indicates that specimen WM 11629 is not Peratobelus nor Dimitobelus.

In Neohibolites the ventral groove extends anteriorly into the stem region, whereas in Parahibolites it is shallow, poorly developed, and confined to the alveolar region. Therefore, if WM 11629 is a Neohibolites, some trace of a ventral groove would probably be apparent in the most anterior stem cross-section (Plate 1, Figure 2).

Although many Parahibolites species have compressed cross-sections (Spengler, 1910, pl. 12, fig. 6, pl. 14, fig. 8; Stolley, 1919, p. 46; Ali-Zade, 1972, p. 185), to judge from specimens of $P$. pseudoduvalia Sinzow from the northern Caucasus (donated to the writer by Dr. G. K. Kabanov, Moscow) and New Guinea specimens of $P$. hlanfordi (Spengler) (Glaessner, 1945) examined by the writer, compression of the cross-section may be confined to the alveolar region, with the stem and apical cross-sections being circular. Thus it is the writer's opinion that the few available characters of specimen WM 11629 suggest its identification as Parahibolites.

Paleobiogeographical Significance: Three faunal realms may be distinguished in the belemnite faunas of the Aptian-Cenomanian (Figure 1).

Boreal belemnites (e.g., Acroteuthis, Oxyteuthis) populated regions such as northern North America, Greenland, and northern U.S.S.R., and have been interpreted as stenothermal organisms adapted to life in cool-temperate seas peripheral to the Cretaceous North Pole (Stevens, 1965a, 1971, 1973; Stevens and Clayton, 1971; Scheibnerova, 1971a, b, c).

A Southern Hemisphere equivalent of the Boreal realm-"Anti-Boreal" or "Austral"-can also be recognized. Austral belemnites (e.g., Peratobelus, Dimitobelus) occur in regions such as New Guinea, Australia, New Zealand, and the Antarctica Peninsula and, like the Boreal belemnites, have been interpreted as 


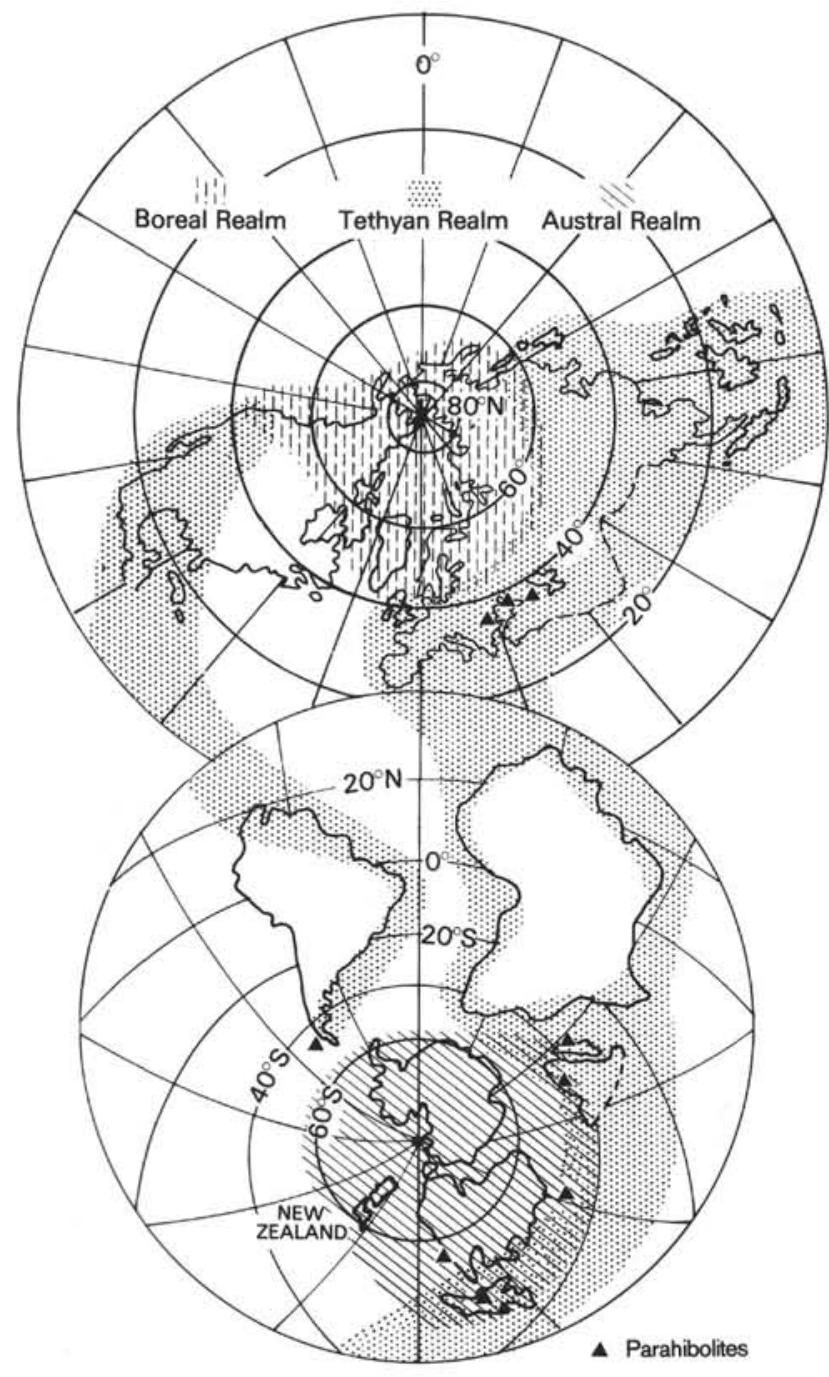

Figure 1. Belemnite palaeobiography in Albian times. After Stevens (1973, fig. 5). Cool-temperate Boreal belemnites populated regions peripheral to the North Pole. Fragmentation of Gondwanaland had been in progress since Middle Jurassic time and by the Aptian and Albian South America and Africa had drifted apart to form the South Atlantic Ocean. Tethyan belemnites, adapted to life in tropical and warm-temperate seas, migrated along the dispersal routes that became available at this time. Movement of Australasia and Antarctica had brought them closer to the South Pole and these regions were populated by cool-temperate Austral belemnites.

The Tethyan belemnite Parahibolites intermingled with Austral belemnites in Queensland, New Guinea, South India and Patagonia. Some recent palaeomagnetic results suggest a slightly more northerly position for Australia than that shown in this diagram (McElhinny, 1970; Embleton, 1973).

(Drawing: Cartographic Section, New Zealand Department of Scientific and Industrial Research.) stenothermal organisms adapted to life in cooltemperate seas peripheral to the Cretaceous South Pole (Stevens, 1973, fig. 5).

Tethyan belemnites (e.g., Parahibolites, Neohibolites, Mesohibolites) populated the Tethyan region of Europe (i.e., countries adjacent to the present-day Mediterranean Sea) and parts of Asia Minor, India, and Southeast Asia. Tethyan belemnites have been interpreted as stenothermal organisms adapted to life in tropical and warm-temperate seas, based on isotopic temperature studies and their association with rudistids, reef corals, and orbitoid foraminifera in the central, presumably circum-equatorial, part of the Tethyan belt (Stevens, 1971).

Areas of overlap between the three realms can be recognized at various times and in various places (Stevens, 1973), and these have been interpreted as climatic gradients (Stevens, 1971).

Parahibolites first appeared in the Aptian, and the only known Aptian occurrences are from Germany (AliZade, 1972, fig. 28). In the Albian, however, the main evolutionary center for Parahibolites shifted southwards, to lie in the Carpathian-Crimean-Caucasian region (Ali-Zade, 1969, fig. 7; 1972, fig. 29). Neohibolites accompanied Parahibolites throughout most of this region, but the range of Neohibolites extended further north, as far as Yorkshire and northern Germany, where it intermingled with the Boreal belemnite Oxyteuthis.

To judge from known occurrences (Stevens, 1965b, 1973), Neohibolites migrated along the Tethyan seaway and other interconnected routes in the Aptian (Stevens, 1965b, fig. 42) and was followed by Parahibolites in the Albian. Stolley's record of Parahibolites fuegensis Stolley from the "Aptian" of southern Patagonia (Stolley, in Richter, 1925; Stevens, 1965b, needs confirmation and may prove to be Albian or Cenomanian (Camacho, 1949).

Apart from the European occurrences in the Albian (Ali-Zade, 1972, fig. 29) Parahibolites is found in New Guinea (Glaessner, 1945; Stevens, 1965b), Queensland (collections of the Geological Survey of Queensland), possibly southern Patagonia (see above), and southern India (Stevens, 1965b). In the four non-European regions Parahibolites is associated with Dimitobelus, and this association is interpreted as being an overlap or transitional zone between the Tethyan and Austral belemnite realms, probably indicating a gradation between warm-temperate and cool-temperate populations (Stevens, 1971, 1973) (Figure 1).

Foraminiferal faunal realms, similar to those based on belemnites, have been distinguished by Scheibnerova (1971a, b, c) who showed Australasia to be wholly populated by Austral faunas in the Cretaceous prior to the Upper Albian.

In the Upper Albian, however, Tethyan elements appeared in western and northern Australia (Scheibnerova, 1971a, b), and this change has been interpreted by Scheibnerova (1971a) as being a consequence of the northward movement of India and the channeling of a warm current down the western flank of Australia. 
It could also be a consequence of rotation and drift of Australia (Wellman et al., 1969; Vilas and Valencio, 1970).

The presence of Parahibolites at Site 263, Cuvier Abyssal Plain, may be interpreted as being part of the influx of Tethyan immigrants that occurred in late Albian time in the northwest and western regions of Australia. The presence of Austral elements in nearby areas, however, (Stevens, 1973) indicates that Parahibolites may have been almost at the limit of its climatic range and that, in this instance, it was probably a warm-temperate, rather than tropical, element.

Age: In Europe Parahibolites ranges from Aptian to Lower Cenomanian (Ali-Zade, 1972). The occurrences of Parahibolites in South America and New Guinea are probably of Albian age, but exact correlations are not available. In southern India, however, Parahibolites occurs in the lowest zone of the Utatur Group (with Stoliczkia dispar [d'Orb], that has been assigned to the Upper Albian (Sastry et al., 1968). In Queensland Parahibolites is associated with the Albian belemnite Dimitobelus diptychus (McCoy) (Day, 1969).

It is therefore concluded that specimen WM 11629 is probably of Albian age, and to judge from the Utatur Group occurrences, Upper Albian.

\section{AMMONOIDEA}

\section{indet. ammonite,}

?cf. Prohysteroceras (Goodhallites) richardsi Whitehouse

Material: One test fragment and internal mold (Plate 1, Figure 4). Sample 263-18-5, $105 \mathrm{~cm}$. Cuvier Abyssal Plain, $23^{\circ} 20^{\prime} \mathrm{S}, 110^{\circ} 58^{\prime} \mathrm{E}$. Water depth 5065 meters, sample from 413.5 to 423 meters below the sea floor. Specimen deposited in the World Mollusca Collection, New Zealand Geological Survey, Lower Hutt, New Zealand. Specimen WM 11628.

Description and Discussion: The fragment consists of a piece of test ornamented with four projected ribs. The test surface has been fractured and distorted along a line about halfway down the whorl side. This distortion has probably slightly altered the character of the ribbing, and although the ribs appear reasonably straight (apart from projection towards the venter), they may have originally been slightly sinuous. The two ribs on the right-hand side of the specimen (Plate 1, Figure 4) appear to converge and join at a point close to the umbilical edge. At the point of convergence there is a slight protuberance, possibly a subdued umbilical tubercle.

Excavation around the edges of the fragment has shown that it does not continue any further into the matrix. It has therefore not been possible to determine the nature of the venter.

Although strictly speaking the fragment is indeterminate, the few available characters suggest placement in subfamily Mortoniceratinae (Upper Albian and Lower Cenomanian). Members of this subfamily are carinate and usually characterized by the presence of many umbilical and ventrolateral tubercles. The presence or absence of a carina is, however, not possible to determine in specimen WM 11628, and the number and shape of tubercles vary considerably in the Mortoniceratinae (Arkell et al., 1957).

The few available characteristics of specimen WM 11628 suggest the possibility that it may be a fragment of Prohysteroceras (Goodhallites) richardsi Whitehouse, and if this is a valid possibility the age thus indicated is early Upper Albian (Whitehouse, 1926; Day, 1969).

Prohysteroceras (Goodhallites) is known from Queensland, southern India, southern Africa, Madagascar, southern England, and Texas (Day, 1969), and this distribution can be interpreted to indicate that like Parahibolites, (see above) it is a Tethyan element that in late Albian time was able to achieve a wide distribution by migrating along the Tethyan seaway and other interconnected routes into the Indo-Pacific region (Day, 1969; Wright, 1963).

\section{REFERENCES}

Ali-Zade, A. A., 1969. Late Cretaceous belemnites of Azerbaidjan: Baku (Azerbaidjan State Press). 1972. Cretaceous belemnites of Azerbaidjan: Moscow (Nedra Publishing House).

Arkell, W. J., Furnish, W. M., Kummel, B., Miller, A. K., Moore, R. C., Schindewolf, O. H., Sylvester-Bradley, P. C., and Wright, C. W., 1957. Mollusca, Cephalopoda, Ammonoidea. Treatise on invertebrate palaeontology Part L: Lawrence, Kansas (Geol. Soc. Am. Kansas Univ. Press).

Camacho, H. H., 1949. La faunula Cretacica del Hito XIX (Tierra del Fuego): Rev. Assoc. Geol. Argentina, v. 4, p. 249.

Day, R. W., 1969. The Lower Cretaceous of the Great Artesian Basin. In Campbell, K. S. W. (Ed.), Stratigraphy and palaeontology: Essays in honour of Dorothy Hill: Canberra (Australian National University Press, p. 140.

Embleton, B. J. J., 1973. The palaeolatitude of Australia through Phanerozoic Time: J. Geol. Soc. Australia, v. 19, p. 475 .

Glaessner, M. F., 1945. Mesozoic fossils from the central highlands of New Guinea: Roy. Soc. Victoria Proc., v. 56, p. 151.

McElhinny, M. W., 1970. Formation of the Indian Ocean: Nature, v. 228, p. 977.

Richter, M., 1925. Beitrage zur Kenntnis der Kreide in Feuerland: Neues Jahrb. Mineral. Geol. Paläontol., v.52, p. 524

Sastry, M. V. A., Rao, B. R. J. and Mamgain, V. D., 1968. Biostratigraphic zonation of the upper Cretaceous formations of Trichinopoly District, South India. In CretaceousTertiary Formations of South India: Geol. Soc. India Mem. 2, p. 10.

Scheibnerova, V., 1971a. Foraminifera and their Mesozoic biogeoprovinces: Geol. Surv., New South Wales Rec., v. 13.

1971b. Implications of Deep Sea Drilling in the Atlantic for studies in Australia and New Zealand-some new views on Cretaceous and Cenozoic palaeogeography and biostratigraphy: Search, v. 2, p. 251 .

197Ic. Palaeoecology and palaeogeography of Cretaceous deposits of the Great Artesian Basin (Australia): Geol. Surv. New South Wales Rec., v. 13.

Spengler, E., 1910. Untersuchungen uber die Sudindische Kreideformation: Die Nautiliden und Belemniten des Trichinopolydistrikts. Beitr. Palaont. Geol. ÖsterreichUngarns Orients, v. 23, p. 125. 
Stevens, G. R., 1965a. Faunal realms in Jurassic and Cretaceous belemnites: Geol. Mag., v. 102, p. 175.

1965b. The Jurassic and Cretaceous belemnites of New Zealand and a review of the Jurassic and Cretaceous belemnites of the Indo-Pacific Region: New Zealand Geol. Surv., Paleontol. Bull., v. 36.

1971. Relationship of isotopic temperatures and faunal realms to Jurassic-Cretaceous palaeogeography, particularly of the south west Pacific: J. Roy. Soc. New Zealand, v. 1, p. 145.

1973. Cretaceous belemnites. In Hallam, A. (Ed.), Atlas of palaeobiogeography. Amsterdam (Elsevier), p. 385.

Stevens, G. R., and Clayton, R. A., 1971. Oxygen isotope studies on Jurassic and Cretaceous belemnites from New
Zealand and their biogeographic significance: New Zealand J. Geol. Geophys., v. 14, p. 829.

Stolley, E., 1919. Die systematik der Belemniten: J. Niedersachs Geol. Ver., v. 11, p. 1.

Vilas, J. F., and Valencio, D. A., 1970. Palaeogeographic reconstructions of the Gondwanic continents based on palaeomagnetic and sea-floor spreading data: Earth Planet. Sci. Lett., v. 7, p. 397.

Wellman, P., McElhinny, M. W., and McDougall, I.,1969. On the polar-wander path for Australia during the Cenozoic: Roy. Astron. Soc. Geophys. J., v. 18, p. 371.

Whitehouse, F. W. 1926. The Cretaceous Ammonoidea of Eastern Australia: Mem. Queensland Museum, v. 8, p. 195.

Wright, C. W. 1963. Cretaceous ammonities from Bathurst Island, Northern Australia: Palaeontology, v. 6, p. 597. 


\section{PLATE 1}

Figures 1-3 cf. Parahibolites, sp. indet. WM 11629, New Zealand Geological Survey. Site 263, Core 26, section 2 .

1. Guard exposed on a cross-section through the drill hole core. The arrows indicate the positions of Figures 2 and $3 . \times 2.5$.

2. Cross-section through the guard at position " $\mathrm{X}$ " in Figure 1. $\times 10$.

3. Cross-section through the guard at position "Y" in Figure 1. $\times 10$.

Figure 4 Indet. Ammonite fragment (?cf. Prohysteroceras (Goodhallites) richardsi Whitehouse) WM 11628, New Zealand Geological Survey. Site 263, Core 18 , section 5. Internal mold. $\times 2.5$.

(Photo: D. L. Homer, New Zealand Geological Survey.) 


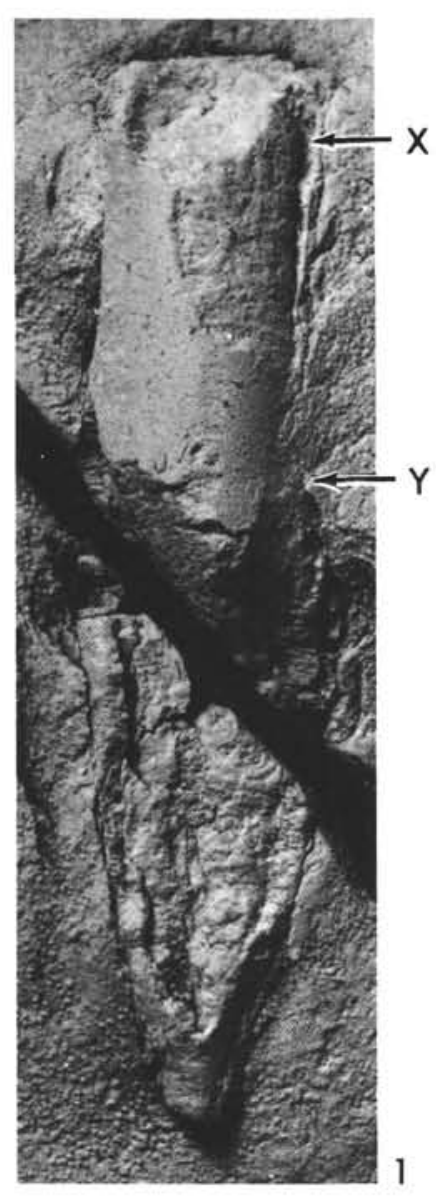

PLATE 1
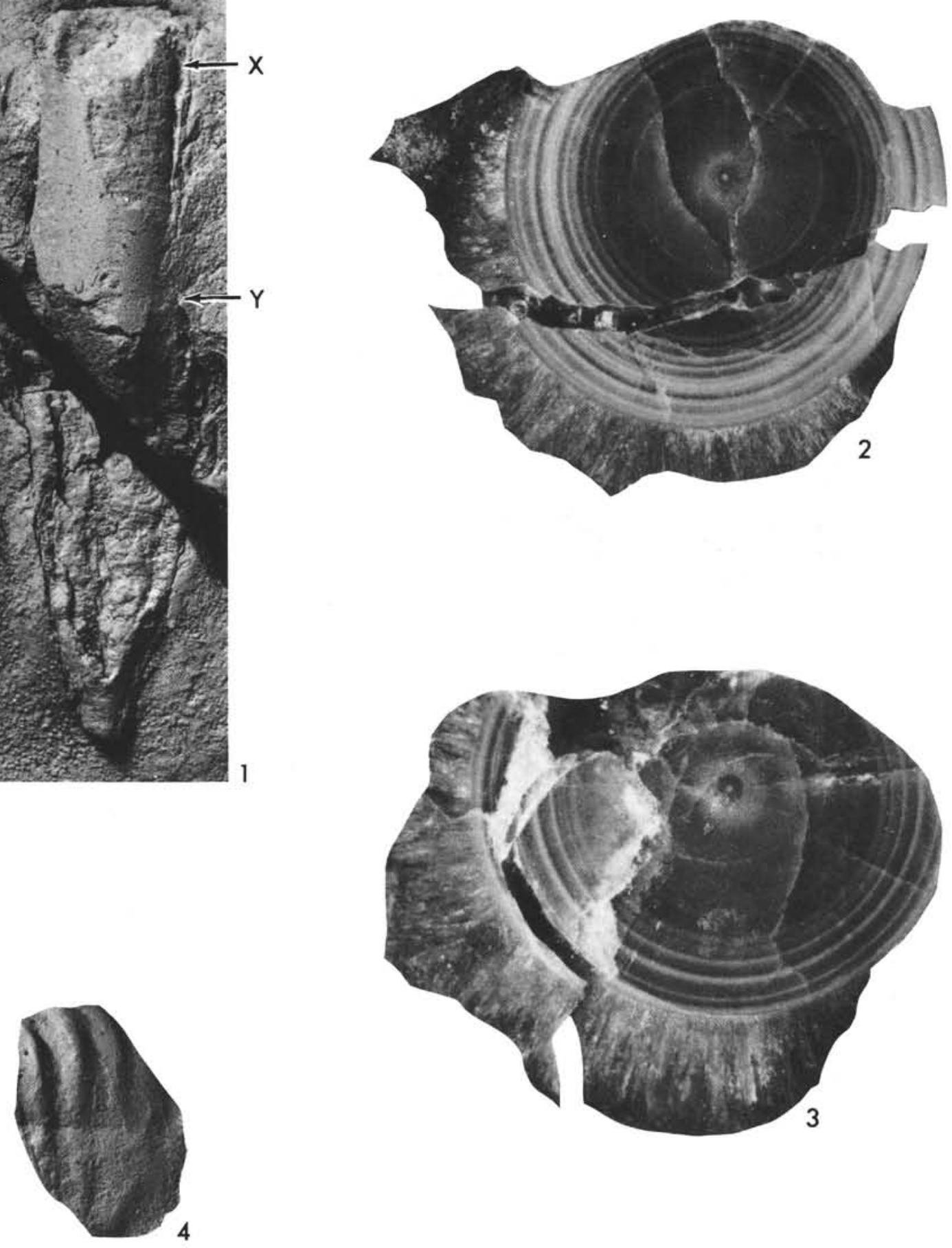